\title{
Supermarkets: The New Scene for Upcoming Dietitians
}

\author{
Essence Leftrige* and Joycelyn Peterson \\ Department Chair, Oakwood University, USA
}

Submission: February 12, 2018; Published: February 20, 2018

*Corresponding author: Essence Leftrige, Department Chair, Oakwood University, Adventist Boulevard Northwest Huntsville, ALUSA, Email: jpeterson@oakwood.edu

\section{Editorial}

Round of applause everyone. The relationship between large food stores and dietary intake has finally received attention. There is a heightened interest among researchers in identifying evidence-based interventions to promote healthy eating practices and studies show that supermarkets are an optimal setting for these types of interventions. According to Dr. Anne L. Escaron and associates, "supermarket and grocery store interventions are consistent with a social ecological approach, and the availability of healthy foods in food stores affect consumers' ability to make healthful dietary choices."

In 2007, Produce for Better Health Foundation (PBH), a nonprofit organization, investigated this environmental strategy for intervention and improvement of the population's eating practices, and collaborated with the Centers for Disease Control \& Prevention (CDC) and other national partners to launch a new and relevant national health initiative: Fruits \& Veggies-More Matters, replacing the "5 A Day for Better Health" campaign.

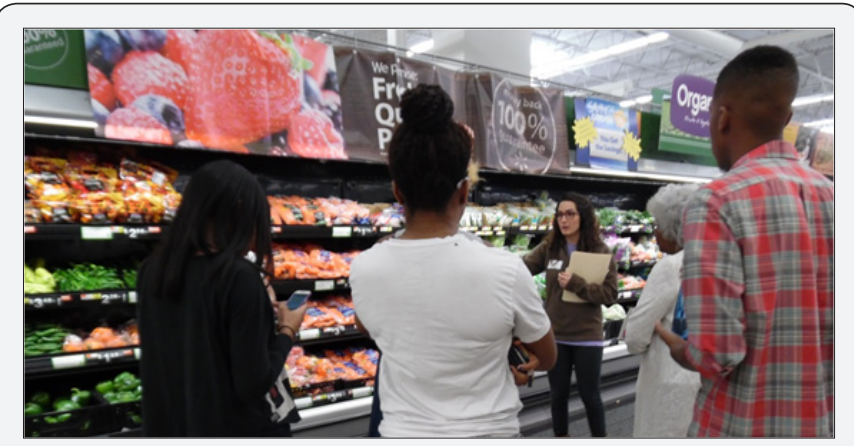

Figure 1: Sixteen dietetic interns were trained by an experienced supermarket registered dietitian.

In light of this new initiative and PBH's recent collaboration between supermarkets and university nutrition and dietetic programs, Oakwood University submitted a grant proposal in the spring of 2014 to participate in the PBH Store Tour Training Program. It became 1 of 8 universities with an accredited Nutrition \& Dietetic Internship to be awarded the $\$ 5,000$ grant

for the January 2015 - June, 302015 school year. The PBH Store Tour Training Program provided Oakwood University's dietetic interns (DIs) the opportunity to develop skills needed to lead grocery store tours, with a particular emphasis on all forms of fruit and vegetables, to groups of peers and/or to community adults (Figure 1).

Sixteen dietetic interns were trained by an experienced supermarket registered dietitian (Dr. Joycelyn Peterson) at partnering supermarkets-Kroger, Walmart, and Publix in Huntsville, Alabama. The interns learned about corporate marketing and private label products. They also learned about common misperceptions about fruit and vegetables. The tours

were designed to offer solutions to the confusion that shoppers often experience when trying to make healthy food choices. Out of 225 tour participants, 175 were Oakwood University students and 50 were community shoppers (non-students) from area churches in Huntsville, Alabama. Sampling fruits and vegetables was a part of the tour, and each tour participant received a brochure including information on the national health initiative, Fruits \& Veggies-More Matters, along with goodie bags filled to the brim with fresh, dried, and canned fruits and vegetables. At the end of each tour, each participant responded to 11 survey questions.

The findings include:

A. When asked, "Do you consider yourself a healthy eater?" 36\% replied yes, 37\% replied maybe, and 11\% said no.

B. $80 \%$ eat fruit and vegetables 2-3 times per day.

C. The majority of the participants visited a grocery store once per week.

D. $75 \%$ of the participants enjoyed tasting fruit and vegetables during the tour.

E. $45 \%$ stated that they tasted a variety of fruit or vegetable for the very first time. 
F. $68 \%$ of the participants agreed that the store tour would make a difference in how many fruit and vegetables they would eat in the future (Figure 2).

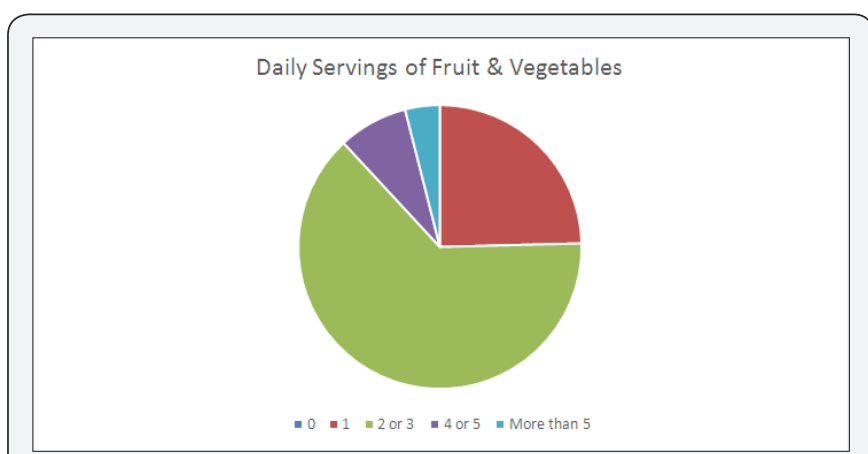

Figure 2 : The majority said that they learned about 5 ways to shop for fruits and vegetables.

\section{Conclusion}

All the grocery store participants enjoyed listening to the DIs share valuable nutrition information. The majority said that they learned about 5 ways to shop for fruits and vegetables, how to shop effectively, how to read nutrition labels and determine serving sizes on fruit and vegetable juices, and how to purchase healthy foods within a budget. More testing of interventions aimed at increasing fruit and vegetable consumption, including their effect on diet and health outcomes, is needed (Figure 3).

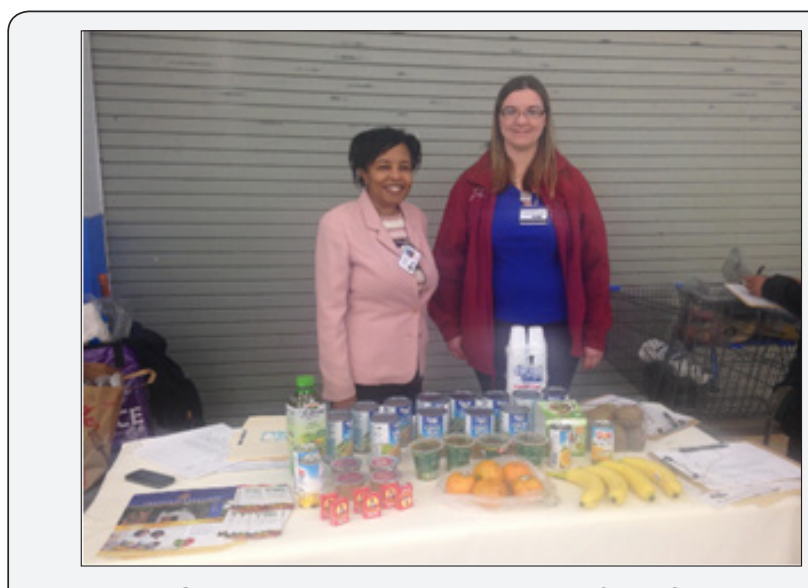

Figure 3 : Grocery store dietetics is a growing field of employment for nutrition professionals.

Grocery store dietetics is a growing field of employment for nutrition professionals. The training of nutrition and dietetics students in this area is invaluable. In the future, there may be numerous dietitians walking alongside consumers in supermarkets across the nation.

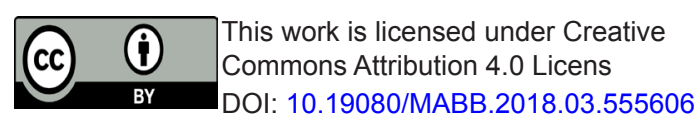

\begin{tabular}{l} 
Your next submission with Juniper Publishers \\
will reach you the below assets \\
- Quality Editorial service \\
- Swift Peer Review \\
- Reprints availability \\
- E-prints Service \\
- Manuscript Podcast for convenient understanding \\
- Global attainment for your research \\
- Manuscript accessibility in different formats \\
( Pdf, E-pub, Full Text, Audio) \\
- Unceasing customer service \\
Track the below URL for one-step submission \\
https://juniperpublishers.com/online-submission.php \\
\hline
\end{tabular}

